Fatih Sahin'

Education Faculty of Gazi University

Turkey

Kubra Yenel

Education Faculty of Gazi University

Turkey
Original scientific paper

UDC: 371.39

DOI: $10.5937 /$ IstrPed2101017S

\title{
RELATIONSHIP BETWEEN ENABLING SCHOOL STRUCTURE, TEACHERS' SOCIAL NETWORK INTENTIONS AND PROFESSIONAL LEARNING COMMUNITY²
}

\begin{abstract}
This study aims to determine the relationships between enabling school structure, teachers' social network intentions and the professional learning community. This study used a structural equation modelling approach to investigate the relationships and implemented the appropriate sampling method. Survey data were obtained from 302 teachers working in the capital city of Turkey. Results show that teachers' perceptions of enabling school structure and social networking intentions among their colleagues are high, and their evaluations of forming a professional learning community are relatively low. When we examined the relationships between variables, we found a positive and moderate relationship between the enabling school structure and teachers' social network intentions; a positive and high relationship between the enabling school structure and the professional learning community. However, a positive but low level of a significant relationship is found between teachers' social network intentions and the professional learning community. Another significant result of the study is that the social network intentions of teachers increase with the enabling school structure. With the increase in social network intentions, the tendency to form a professional learning community also increases. Some suggestions were made for researchers and school communities in the research, both on becoming professional learners and creating better social networks.
\end{abstract}

Keywords: enabling school structure, social network intentions, professional learning community.

\section{Introduction}

There have been significant numbers of studies suggesting that the bureaucratic structure of the school is related to several critical organisational factors, such as creativity, job satisfaction, motivation, conflict, school climate, organisational trust and leadership (Adler \& Borys, 1996; Buluc, 2010; Geist, 2002; Hoy \& Sweetland, 2001; Jacob, 2004; Mcvey, 2009). Much organisational research focuses on the negative aspects of the bureaucratic organisational structure. There are claims that bureaucratic organisation suppresses creativity, increases

\footnotetext{
${ }^{1}$ sahinfatih@gazi.edu.tr

${ }^{2}$ This study has been orally presented at 14th Congress of Educational Administration, on 2-4 May, 2019, Cesme, Izmir, Turkey
} 
dissatisfaction and lowers employee motivation (Adler \& Borys, 1996). Sorensen's (2007) research showed that working in more bureaucratic organisations makes people less likely to launch their business ventures. However, the bureaucratic organisational structure also has an enabling effect on organisational actions (Gonullu, 2009; Hoy \& Sweetland, 2001; Kalkan, 2016; Ozturk; 2001; Wu et al., 2013). Hoy and Sweetland (2001) stated that bureaucratic structures might have harmful aspects, but only half the picture. According to Gonullu's (2009) research, the communication and interaction skills of the teachers decrease when the use of hierarchical authority increases and teacher competence increases as the facilitating bureaucratisation increases.

Specifically, there have been significant numbers of studies suggesting that the enabling structure of the school is related to several critical organisational factors, such as the culture of academic optimism, collective responsibility etc. (Wu et al., 2013).

Buluc's (2010) study shows that transformational leadership behaviours are higher in enabling bureaucratic organisations. Hoy and Sweetland's (2001) research shows that the more the bureaucratic organisation structure is enabling, the fewer employees conceal reality, and the fewer employees have a conflict of roles while the employees have more confidence in their school administrators. Moreover, the study of Kalkan (2016) shows that there is a positive relationship between enabling school bureaucracy and organisational trust.

The bureaucratic organisational structure is also an essential factor in organisational socialisation (Erdogan, 2012). Therefore, especially the enabling school structure is thought to impact the social network intentions of teachers because the enabling bureaucracy shows characteristic features such as engaging in interactive dialogues, developing trust, and valuing differences. In addition, such a structure is also characterised by employment security, professional perspective, cohesive workgroups, limited management-labour conflict, employee participation, coordination for improvement, and so on (Hoy \& Sweetland, 2001).

Kalkan's (2016) research showed that as teachers' perception of enabling school bureaucracy increased, their perceptions of the professional learning community increased. Therefore, it is believed that the facilitating school structure will also contribute to the transformation of schools into professional learning communities. Because in organisations with strong social networks, the tendency to form a professional community is also expected to be high (Giles \& Hargreaves, 2006). The belief that bureaucracy will contribute to the development of social networks makes such a result possible. The social network structure is associated with the professional learning community, and the professional learning community is associated with many organisational factors such as school structure, successful teaching practices, trust among colleagues and student achievement (Gray et al., 2016; Kalkan, 2016; Liou \& Daly, 2014; Lomos et al., 2011; Moolenaar et al., 2012; Vescio et al., 2008). So it is essential to determine the relationship between the bureaucratic structure of the school and the professional learning community directly and through the teachers' social network intentions. This study aims to determine the relationship between enabling school structure, teachers' social network intentions and the professional learning community according to teachers' perceptions. In this study, the following questions were sought for this purpose:

1. To what extent does the enabling school structure, teachers' social network intentions, and the professional learning community occur in schools?

2. What is the degree and effect of the enabling school structure on teachers' social network intentions and the professional learning communities? 


\section{Theoretical Framework}

\section{Bureaucratic Organisational Structure}

Hoy and Sweetland (2001) state that two main features stand out in bureaucratic organisations. These are formalisation and centralisation (hierarchy of powers). Formalisation is a concept that reflects the degree of written rules, procedures, regulations or policies in the organisation. Centralisation is a concept that reflects the degree of participation of employees in the decisionmaking process and shows who is in control of the organisation.

When the literature on bureaucratic organisations is examined, it is seen that bureaucracy may be both supportive and preventive for organisations. Hoy and Sweetland $(2000,2001)$ discussed the bureaucratic structure in two different ways with the possible aspect of enabling and complicating effect of the school. Adler and Borys (1996) argue that there are two conflicting views of the bureaucratic organisational structure in organisational research. In the cynical view, the form of bureaucratic organisation complicates creativity, increases dissatisfaction and adversely affects the motivation of employees. According to the optimistic view, the bureaucratic organisation provides the necessary guidance and clarifies the responsibilities. Thus, role-related stress of the employees is reduced, and they consider themselves more productive.

\section{Social Network Theory}

Social network theory is an essential concept in understanding and analysing educational organisation ( $\operatorname{Er} \&$ \& Calik, 2017). Social network theory emphasises social capital in the organisation and tries to explain the interactions among individuals (Liou \& Daily, 2014). In organisations, individuals have different social network intentions (Moolenaar et al., 2014). People with powerful social network connections are more efficient and productive than individuals with low network connections because they are more involved in a broader network and have greater access to information (Liou \& Daily, 2014). Social network intentions are addressed in four dimensions: actively seeking relationships, liking to connect, belief in having the right relationships, and assessing relationships (Cohen et al., 2011; Moolenaar et al., 2014). However, in Er and Calik (2017) study, social network intentions emerged in three dimensions (other dimensions except liking to connect).

\section{Professional Learning Community}

In the literature, it is seen that different definitions of the professional learning community are made, and concepts such as professional community or learning community are used concerning this concept. Lomos et al. (2011) mentioned the complexity of the concept by emphasising that this concept mainly focused on the concepts of colleague solidarity, cooperation, a shared focus on student learning and a shared goal. It can be argued that there is a supportive and shared leadership in professional learning communities, shared values and vision, collective learning activities, shared individual practices and supporting conditions in the relationship or structure dimension (Bellibas et al., 2017). Also, supportive school culture is essential to a professional learning community (Tabak \& Sahin, 2020).

\section{Method}

\section{Research Model}

This research aims to determine the relationship between teachers' perceptions of enabling school structure, teachers' social network intentions and the professional learning community. 
Therefore, the research design was determined as a correlational survey model. According to Brink and Wood (1998), correlational survey models are research models aiming to determine the presence and degree of interchange between two or more variables within the context of the related literature. There are three variables in the research model: one independent/external variable (enabling school structure) and two dependent/internal variables (social network intentions and professional learning community). In this study, the structural equation modelling was used to determine the effect of the variable of enabling school structure on the social network intentions of teachers and the professional learning community, either directly or indirectly. Structural equation modelling (SEM) is a holistic analysis that extends the predictive structural relation between variables in the regression model and the latent factor structures in factor analysis (Tabachnick \& Fidell, 2007).

\section{Population and Sample}

The population of the study consists of teachers working at public schools. The population sample was determined by the appropriate sampling method. 327 teachers in 30 public schools from Ankara, Turkey, were reached for the sample. These schools were the schools where the postgraduate students were going on education at Gazi University Educational Administration Department. However, as explained in the data analysis, 16 questionnaires were excluded during the pre-analysis data screening stage, and nine questionnaires were excluded because of having extreme values during the analysis. The remaining 302 questionnaires were analysed. Table 1 shows the distribution of the teachers who participated in the study regarding gender, age, professional seniority and branch variables.

Table 1. Distribution of Demographic Variables of Teachers

\begin{tabular}{|c|c|c|c|}
\hline Variable & Category & $N$ & $\%$ \\
\hline \multirow{3}{*}{ Gender } & Male & 163 & 54 \\
\hline & Female & 139 & 46 \\
\hline & Total & 302 & 100 \\
\hline \multirow{5}{*}{ Age } & $24-33$ & 49 & 16.2 \\
\hline & $34-43$ & 153 & 50.7 \\
\hline & $44-53$ & 87 & 28.8 \\
\hline & $54-63$ & 13 & $4 \cdot 3$ \\
\hline & Total & 302 & 100 \\
\hline \multirow{5}{*}{ Professional Seniority } & $1-9$ & 55 & 18.2 \\
\hline & $10-19$ & 138 & 45.7 \\
\hline & $20-29$ & 94 & 31.1 \\
\hline & $30-39$ & 15 & 5 \\
\hline & Total & 302 & 100 \\
\hline \multirow{3}{*}{ Branch } & Elementary School Teacher & 76 & 25.2 \\
\hline & Branch Teacher & 226 & 74.8 \\
\hline & Total & 302 & 100 \\
\hline
\end{tabular}

When Table 1 is examined, it is seen that approximately half of the participants are women, their ages vary between 24 and 63 , and the average age is 40 . Besides, it is noteworthy that the majority of the teachers in the sample are secondary education teachers, their seniority range from 1 to 39 years, the average professional seniority is 16 years, and about half of them have seniority of 10-19 years.

\section{Data Collection Tools}

In the study, the Enabling Bureaucracy Scale (EBS), Network Intentionality (NI) Scale and Professional Learning Community Assessment - Revised (PLCA-R) Scale were used as data 
collection tools. Necessary permissions were obtained for the use and application of the measurement tools determined for the research; in addition to these scales in the data collection tool, the research form has a section that includes the personal information of the participants on gender, age, professional seniority and branches.

\section{EBS}

This scale was developed by Hoy and Sweetland (2000) and adapted to Turkish by Buluc (2009). EBS is composed of one dimension and 12 items. The Cronbach's Alpha reliability coefficient of the scale is .87. In this Likert-type scale, the items are coded as (1) never, (2) occasionally, (3) sometimes, (4) often and (5) always.

\section{NI}

This scale was developed by Cohen et al. (2011) and adapted to Turkish by $\operatorname{Er}$ (2017). NI consists of 12 items and three sub-dimensions: assessing relationships (4 items), actively seeking relationships (4 items), and belief in having the right relationships ( 4 items). Cronbach's Alpha reliability coefficient is calculated as .84 . The items in this 5-point Likert-type measuring instrument are coded as (1) totally disagree, (2) disagree, (3) moderately agree, (4) agree and (5) totally agree.

\section{PLCA-R}

This scale was developed by Olivier et al. (2003) and adapted to Turkish by Bellibas et al. (2017). PLCA-R consists of 52 items and six sub-dimensions: shared and supportive leadership (11 items), shared values and vision ( 9 items), collective learning and application (10 items), shared personal practice (7 items), supportive conditions-relationships ( 5 items) and supportive conditions-structures (10 items). The Cronbach's Alpha reliability coefficient of the scale is .95. The items in this Likert type scale are coded as (1) strongly disagree, (2) disagree, (3) agree and (4) absolutely agree.

\section{Data Collection and Analysis}

327 questionnaires were delivered to the teachers working in schools in the sample group. However, in the first examination, it was determined that 16 questionnaires were not completed in line with the directive rules. Therefore, these questionnaires were excluded from the sample. As a result, 311 questionnaires were evaluated. SPSS 21.0 and LISREL 8.80 statistical package programs were used for data analysis. The descriptive analysis of the variables was done through the SPSS program. In order to test the effectiveness of the social network intentions on the professional learning community and the effectiveness of the school structure on the social network intentions, the path analysis technique was used through the LISREL program. Path analysis is used to test the existence of a causal relationship between three or more variables (Fraenkel \& Wallen, 2009).

When evaluating the model with path analysis, several criteria, generally called fit index, are used to determine the model's suitability. In addition, to calculate the value of the path coefficients, the LISREL program also allows the fit indexes to be calculated for testing the model. The most commonly used fit indexes in scientific studies are Chi-Square statistic $\left(\chi^{2}\right)$, Root-Mean-Square Error Approximation (RMSEA), Standardised Root Mean Square Residuals (SRMR), Non-Normed Fit Index (NNFI), Comparative Fit Index (CFI), Goodness of Fit Index (GFI), and Adjusted Goodness-of-Fit Index (AGFI) (Joreskog \& Sorbom, 1996). 
Before starting the data analysis, the missing values were examined to determine if there was any missing data related to the variables. The variable sets determined that there were no missing data because the missing questionnaires were identified and excluded from the research before the data was analysed. In the next stage, the extreme values were examined. The extreme values were removed by looking at the $Z$ values of each sample (except for the +4 and -4 range). Extreme values mean the excess value of the sample in a variable or an excess value for a combination of variables. The extreme value analysis determined that gobservations in the data set showed multivariate extreme values $(p<0.01)$. For this reason, gobservations were excluded from the data set, and the data set was analysed with 302 data. Then, the normality test was performed on the final data, and it was found that the data provided the assumption of multivariate normality ( $p>0.05)$. As a result of missing values, extreme values and normality test analysis, 302 questionnaires were taken into consideration in the data set, thus providing the necessary conditions for analysing the data.

\section{Findings}

Firstly, the statistics about the enabling school structure, social network intentions and professional learning community were given according to the teachers' perceptions (see Table 2). Then, the findings of the path analysis conducted to test the relationships between the enabling school structure, teachers' social network intentions and the assessment of the professional learning community were included.

Table 2. Descriptive Statistics on Enabling School Structure, Teachers' Social Network Intentions and Assessment of Professional Learning Community $(n=302)$

\begin{tabular}{|c|c|c|c|c|}
\hline Scales & Sub-Scales & Item Number & $M$ & $S D$ \\
\hline Enabling School Structure & - & 12 & 4.14 & 0.64 \\
\hline \multirow{4}{*}{ Network Intentionality } & Assessing relationships & 4 & 3.84 & 0.76 \\
\hline & Actively seeking relationships & 4 & 4.41 & 0.58 \\
\hline & $\begin{array}{l}\text { Belief in having the right } \\
\text { relationships }\end{array}$ & 4 & 4.36 & 0.68 \\
\hline & Total & 12 & 4.20 & 0.55 \\
\hline \multirow{7}{*}{$\begin{array}{l}\text { Professional Learning } \\
\text { Communities } \\
\text { Assessment - Revised }\end{array}$} & $\begin{array}{lll}\begin{array}{l}\text { Shared } \\
\text { leadership }\end{array} & \text { and supportive } \\
\end{array}$ & 11 & 3.31 & 0.55 \\
\hline & Shared values and vision & 9 & 3.20 & 0.56 \\
\hline & $\begin{array}{lll}\begin{array}{l}\text { Collective } \\
\text { application }\end{array} & \text { learning and } \\
\end{array}$ & 10 & 3.08 & 0.59 \\
\hline & Shared personal practice & 7 & 3.07 & 0.59 \\
\hline & $\begin{array}{l}\text { Supportive } \\
\text { relationships }\end{array}$ & 5 & 3.21 & 0.61 \\
\hline & $\begin{array}{l}\text { Supportive } \\
\text { structures }\end{array}$ & 10 & 3.05 & 0.56 \\
\hline & Total & 52 & 3.15 & 0.50 \\
\hline
\end{tabular}

\section{Findings Related to the First Sub-Problem}

According to the teachers' perceptions, enabling school structure $(M=4.14)$ is found to be high. According to the perceptions of the teachers, the highest point is given to the 11th item of the enabling school structure scale "In this school, the authority of the principal is used to undermine teachers" (a reverse-coded item, $M=4.64$ ), and the fewer point is given to the 2nd item "Bureaucratic formalities is a problem in this school." 
According to the perceptions of teachers, it is seen that the highest value for the social network intentions scale is given to the dimension of actively seeking relationships $(M=4.41)$. Belief in having the right relationships $(M=4.36)$ follows this dimension. The lowest value is given to the assessing relationships dimension $(M=3.84)$. When the standard deviation values are considered, it is seen that the most homogeneous distribution is in the dimension of actively seeking relationships $(S D=0.58)$. In contrast, the most heterogeneous distribution is seen in the dimension of assessing relationships (SD $=0.76)$. In other words, it can be asserted that teachers' social network intentions are high $(M=4.20)$.

It is seen that the teachers give the highest value to the professional learning community to the dimension of Shared and Supportive Leadership ( $M=3.31)$. Supportive Conditions-Relationships $(M=3.21)$ follow this.) The lowest value is seen in Supportive Conditions - Structures $(M=3.05)$. When the standard deviation values are examined, it is seen that the most homogenous distribution is in the Shared and Supportive Leadership dimension $(S D=0.55)$ and the most heterogeneous distribution is in the Supportive Conditions - Relationships dimension $(S D=0.61)$. In other words, it can be said that teachers assess the professional learning communities at a moderate level $(M=3.15)$ for their schools.

\section{Findings Related to the Second Sub-Problem}

Path analysis was conducted to determine the effect of enabling school structure on teachers' social network intentions and their evaluation of professional learning communities and the direction of this effect. Direct and indirect effects of predictor variables on predicted variables are determined by path analysis (Kline, 2011).

This study assumes that the enabling school structure will affect the teachers' social network intentions and the level of professional learning community assessment, and social network intentions will predict the status of assessment of professional learning communities. Besides, it is envisaged that the enabling school structure will, directly and indirectly, affect the teachers' assessment level of the professional learning community. A latent variable in the model is defined as an external variable (enabling school structure); two latent variables are defined as internal variables (social network intentions and professional learning communities).

The research accepts that 12 independent items of the enabling school structure scale explain the independent latent variable. It has been accepted that the latent dependent variable of social network intentions will be explained by the indicators of "actively seeking relationships, belief in having right relationships and assessing relationships". In addition, it has been accepted that the latent dependent variable of professional learning community assessment will be explained by the indicators of "shared and supportive leadership, shared values and vision, collective learning and application, shared personal practice, supportive conditions relationships and supportive conditions - structures".

Firstly, the findings of the statistical suitability of SEM were investigated. Kline (2011, p. 204) recommends that the $\chi_{2} /$ sd ratio, in which the $\chi_{2}$ value is examined in conjunction with sd, is used as a criterion for suitability when evaluating the model's fit. In this study, the $\chi_{2}$ / sd value was found as 2.76 . In other words, the data set is perfectly compatible with the model (Kline, 2011, p. 204). Then, the alternative fit indexes for the model were examined. The findings are given in Table 3.

Table 3. Fit Indexes of the Model for Path Analysis 


\begin{tabular}{llllllll}
\hline$X^{2}$ & $\left(X^{2} / s d\right)^{*}$ & RMSEA & SRMR & NNFI & CFI & GFI & AGFI \\
\hline 504.89 & 2.76 & 0.076 & 0.071 & 0.95 & 0.96 & 0.86 & 0.83 \\
\hline
\end{tabular}

$* s d=183, p<0.01$

Table 3 shows that the degree of freedom of the model has an excellent fit $\left(X^{2} / s d<3\right)$; RMSEA value $(0,05 \leq R M S E A \leq 0,08)$ has an adequate fit (Sumer, 2000, p. 61); SRMR value (SRMR $\leq 0,08)$ shows good fit (Hu \& Bentler, 1999, p. 26); NNFI value (NNFI $\geq 0,95)$ shows perfect fit (Sumer, 2000, p.61); CFI value (CFI $\geq 0.95$ ) is in perfect fit (Hu \& Bentler, 1999, p. 27); and GFI and AGFI values are acceptable. Thus, it is seen that the model generally shows good fit values and is confirmed.

The critical N (Critical N-CN) value of the adequacy of the research sample was calculated as 142.33. This value shows that 302 samples used in the study are sufficient. The SEM results of the research model are given in Table 4:

Table 4. SEM Results of the Research Model

\begin{tabular}{|c|c|c|c|}
\hline Latent / Observed Variables & t-value * & Standardised Loads & $R^{2}$ \\
\hline \multicolumn{4}{|l|}{ Enabling School Structure } \\
\hline Item 1 & 10.12 & 0.57 & 0.32 \\
\hline Item 2 & 7.36 & 0.42 & 0.18 \\
\hline Item 3 & 10.76 & 0.60 & 0.36 \\
\hline Item 4 & 8.72 & 0.50 & 0.25 \\
\hline Item 5 & 12.41 & 0.67 & 0.45 \\
\hline Item 6 & 10.02 & 0.57 & 0.32 \\
\hline Item 7 & 10.67 & 0.60 & 0.36 \\
\hline Item 8 & 9.91 & 0.56 & 0.31 \\
\hline Item 9 & 8.03 & 0.47 & 0.22 \\
\hline Item 10 & 13.98 & 0.72 & 0.52 \\
\hline Item 11 & 9.67 & 0.55 & 0.30 \\
\hline Item 12 & 9.05 & 0.52 & 0.27 \\
\hline \multicolumn{4}{|l|}{ Social Network Intentions } \\
\hline Assessing relationships & & 0.60 & 0.36 \\
\hline Belief in having right relationships & 9.08 & 0.75 & 0.56 \\
\hline Actively seeking relationships & 9.08 & 0.82 & 0.67 \\
\hline Professional Learning Community & & & \\
\hline \multicolumn{4}{|l|}{ Assessment-Revised } \\
\hline Shared and supportive leadership & & 0.80 & 0.64 \\
\hline Shared values and vision & 17.82 & 0.88 & 0.77 \\
\hline Collective learning and application & 17.20 & 0.86 & 0.74 \\
\hline Shared personal practice & 15.78 & 0.81 & 0.66 \\
\hline Supportive conditions - relationships & 17.73 & 0.88 & 0.77 \\
\hline Supportive conditions - structures & 16.03 & 0.82 & 0.67 \\
\hline Structural Relations & t-value & Standardized Loads & \\
\hline $\begin{array}{l}\text { Enabling School Structure } \rightarrow \text { Social } \\
\text { Network Intentions }\end{array}$ & $4.57^{*}$ & 0.34 & \\
\hline Enabling School & $8.21 *$ & 0.52 & \\
\hline $\begin{array}{l}\text { Professional Learning Community } \\
\text { Assessment }\end{array}$ & & & \\
\hline Social Network Intentions $\rightarrow$ & $4 \cdot 34^{*}$ & 0.28 & \\
\hline $\begin{array}{l}\text { Professional Learning Community } \\
\text { Assessment }\end{array}$ & & & \\
\hline Structural Relations & & & $\mathrm{R}^{2}$ \\
\hline Professional Learning Community Ass & 0 & & 0.38 \\
\hline
\end{tabular}


Social Network Intentions $=0.34$ Enabling School Structure

$* p<0.01$

With LISREL, beta $(\beta)$ is the correlation coefficient that indicates the regression of a dependent (internal) latent variable on another latent dependent variable, and gamma $(\gamma)$ is the correlation coefficient that indicates the regression of an independent (external) latent variable on a latent dependent variable. Besides, the coefficient of determination $\left(R^{2}\right)$ describes how much of the observed variation in the structural equation is explained. The factor loads between the latent variable and the observed variable are indicated by lambda $(\lambda)$ (Celik \& Yilmaz, 2013, p. 17). When the findings of the model are examined, the best indicator of the enabling school structure is item $10(\lambda=0.72 ; t=13.98)$; and the best indicator of social network intentions is actively seeking relationships $(\lambda=0.82 ; t=9,08)$; the best indicator of the professional learning communities assessment is shared values and vision $(\lambda=0.88 ; t=17.82)$ and supportive conditions - relationships $(\lambda=0.88 ; t=17.73)$. In other words, enabling school structure is mostly explained by item 10, social network intentions are mostly explained by the dimension actively seeking relationships, and the dimensions mostly explain professional learning communities assessment shared values and vision, and supportive conditions - relationships.

There is a moderate and positive correlation between enabling school structure and the social network intentions of the teachers $(\gamma=0.34 ; t=4.57)$. In other words, enabling school structure positively changes the social network intentions of the teachers.

There is a high positive correlation between enabling school structure and professional learning community $(\gamma=0.52 ; t=8.21)$. In other words, as enabling school structure increases, there happens a positive change in teachers' social network intentions.

A low, positive and significant relationship is found between the social network intentions of the teachers and their assessment of the professional learning community $(\beta=0.28 ; t=4.34)$. In other words, as teachers' level of social networking intentions increases, the level of professional learning community also increases.

Enabling school structure $(\gamma=0.34)$ explains $11 \%$ of social network intentions alone, and again enabling school structure $(\gamma=0.64)$ explains $38 \%$ of the professional learning communities alone. Enabling school structure $(\gamma=0.54)$ and social network intentions $(\beta=0.29)$ together account for $44 \%$ of professional learning communities. This finding can be interpreted as that $44 \%$ of the total change in the variable of professional learning communities is explained by the combined effect of enabling school structure and social network intentions of teachers. In other words, as the enabling school structure increases, teachers' social network intentions and the level of assessment of professional learning communities increase too.

\section{Discussion, Conclusion and Suggestions}

This study examines the possible relationships among enabling school structure, teachers' social network intentions and forming a professional learning community. For this purpose, we tried to define the enabling school structure, social network intentions in the school, and teachers' assessment of the professional learning community. First, when the findings of the enabling school structure are examined, it is seen that teachers' perceptions about enabling school structure are high. In other words, according to the results of the research, the enabling 
school bureaucracy scores are higher than the complicating school bureaucracy scores. Similar results are seen in the studies investigating school structure in Turkey (Buluc, 2010; Kalkan, 2016). In similar studies, it was found that the enabling bureaucracy was perceived more than the complicating bureaucracy in schools (Erdogan, 2012; Ozer, 2010). These similar findings in the literature show that teachers pay attention to facilitating arrangements rather than standard rules in their schools and consider enabling bureaucracy necessary for their interpersonal relations.

The results show that teachers' social network intentions are very high in actively seeking relationships, and they are high in assessing relationships and believing in having the right relationships. In the study of Er and Calik (2017), it is seen that there is a similar ranking, especially in terms of actively seeking relationships. The social network intentions are seen to be high. Determining teachers' social network intentions is essential in understanding and analysing educational organisations (Er \& Calik, 2017).

When teachers' opinions regarding the assessment of the professional learning community are examined, it is seen that teachers' perceptions about shared and supportive leadership are very high. Shared values and vision, collective learning and application, shared personal practice, supportive conditions-relationships, and supportive conditions-structures were relatively lower but similarly high and positive. In the study conducted by Ogdem (2015) to determine the level of being a professional learning community, it was concluded that schools had a medium level in all dimensions. In addition, Bellibas et al. (2017) also found similar findings in their research. Compared to the findings of this study, although the perceptual scores were lower, higher scores for the professional learning community were obtained in all dimensions except for the supportive conditions-structures.

When the results of the second sub-problem of the study are examined, it is seen that the enabling school structure has a positive and significant explanation of the scores of both the teachers' social network intentions and the assessment of the professional learning community. In other words, the school's enabling bureaucratic structure (the facilitating school bureaucracy) contributes to the high social network intentions in the school and the transformation of the school into a professional learning community. Although there is not a considerable study on the relationship between enabling school structure and social network intentions in the literature, it is known that the enabling bureaucratic structure in schools is significantly associated with many organisational variables. Some of these variables are organisational commitment (Tuzel, 2010), school culture (Zeytin, 2008) and organisational trust (Geist, 2002). Therefore, it is known that the bureaucratic structure is dominant in educational organisations, and it is thought that social relations can be affected by this perception. The study of Erdogan (2012) demonstrating a moderately significant relationship between enabling bureaucracy and organisational socialisation coincides with the finding that the enabling bureaucracy that emerged in this study has a moderately significant relationship with the social network intentions of teachers.

The finding that enabling bureaucratic organisational structure has a high level of significant relationship with the professional learning community coincides with the finding that the enabling school structure is positively associated with the professional learning community in the study of Kalkan (2016), in which she examined organisational trust as a mediator variable. Defining professional learning community as teachers' sharing of their professional knowledge, practice and experience; learning activities in school as the primary purpose; and finally having 
different actors interacting at school (Ogdem, 2015) leads to the idea that professional learning communities can be influenced by the social network intentions of teachers in schools. Indeed, in this study, it was found that the relationship between the social network intentions of teachers and the professional learning community was significant. It is thought that teachers in schools will not be enough to make efforts to increase student success individually without having enough interaction with their colleagues. For this reason, the social network intentions of teachers can be seen as a step towards becoming a professional learning community. Hord (2004) emphasises that teachers need to change their isolated and unaware work habits to strengthen schools' learning culture.

Based on the research results, it can be argued that firstly enabling organisational structures should be formed to transform schools into a professional learning community. Organisations with enabling bureaucracy support the professional learning community and contribute to this community through the development of social network ties in the school.

This study covers just a few factors related to the school community. However, the school community has significant variable factors inside to be handled. The importance of the social network of teachers is of high importance recently. Researchers can study the variables affecting the social network level in the school and other organisational behaviours. We also encourage further research on how enabling school structure and professional learning community co-exist, considering the networks of teachers from an integrated perspective.

\section{Acknowledgements}

We have no known conflict of interest to disclose.

\section{References:}

Adler, P. S., \& Borys, B. (1996). Two types of bureaucracy: Enabling and coercive. Administrative Science Quarterly, 41(1), 61-89.

Bellibas, M. S., Bulut, O., \& Gedik, S. (2017). Investigating professional learning communities in Turkish schools: The effects of contextual factors. Professional Development in Education, 43(3), 353-374. https://doi.org/10.1080/19415257.2016.1182937

Brink, P. J., \& Wood, M. J. (1998). Advanced design in nursing research. Sage.

Buluc, B. (2010). The relationship between bureaucratic school structure and leadership styles of school principals in primary schools. Education and Science, 34(152), 71-86.

Celik, H. E., \& Yilmaz, V. (2013). LISREL 9.1 ile yapisal esitlik modellemesi: Temel kavramlar, uygulamalar, programlama. Ani.

Cohen, A., Klein, K., Daly, A. J., \& Finnigan, K. (2011). Out with the old, in with the new: When are leader successions successful. New Directions in Leadership Annual Meeting. The Wharton School of Business University of Pennsylvania.

Er, E., \& Calik, T. (2017). The relationships between primary school teachers' social network tendency and perceptions on social network structure of the school. Gazi Üniversitesi Gazi Eğitim Fakültesi Dergisi, 37(3), 1061-1083. https://doi.org/10.17152/gefad.338136

Erdogan, U. (2012). Ilkogretim okullarinin burokratik yapilari ile ogretmenlerin orgutsel sosyallesme duzeyleri arasindaki iliski (Master Thesis). Retrieved from YOK Tez Merkezi. (314199.) 
Fraenkel, J. R., \& Wallen, N. E. (2009). How to design and evaluate research in education. McGrawHill Higher Education.

Geist, J. R. (2002). Predictors of faculty trust in elementary schools: Enabling bureaucracy, teacher professionalism, and academic press (Unpublished Doctoral Dissertation). Retrieved from the database ProQuest Digital Dissertation. (UMI Number: 3081919).

Giles, C., \& Hargreaves, A. (2006). The sustainability of innovative schools as learning organisations and professional learning communities during standardised reform. $\begin{array}{lll}\text { Educational Administration } \quad \text { Quarterly, } & \text { 42(1), }\end{array}$ https://doi.org/10.1177/0013161X05278189

Gray, J., Kruse, S., \& Tarter, C. J. (2016). Enabling school structures, collegial trust and academic emphasis: Antecedents of professional learning communities. Educational

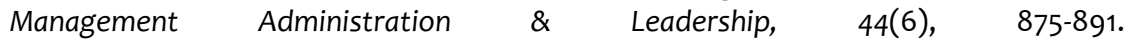
https://doi.org/10.1177/1741143215574505

Hord, S. M. (2004). Professional learning communities: Communities of continuous inquiry and improvement. Texas: Southwest Educational Development Laboratory.

Hoy, W. K., \& Sweetland, S. R. (2000). School bureaucracies that work: Enabling, not coercive. Journal of School Leadership, 10, 524-541. https://doi.org/10.1177/105268460001000603

Hoy, W. K., \& Sweetland, S. R. (2001). Designing better schools: The meaning and measure of enabling school structures. Educational Administration Quarterly, 37(3), 296-321. https://doi.org/10.1177/00131610121969334

Hu, L., \& Bentler, P. M. (1999). Cutoff criteria for fit indexes in covariance structure analysis: Conventional criteria versus new alternatives. Structural Equation Modeling: A Multidisciplinary Journal, 6(1), 1-55. https://doi.org/10.1080/10705519909540118

Jacob, J. A. (2004). A study of school climate and enabling bureaucracy in select New York City public elementary schools (Unpublished Doctoral Dissertation). Retrieved from the database ProQuest Digital Dissertation. [UMI Number: 3166881].

Joreskog, K. G., \&Sorbom, D. (1996). LISREL 8: User's reference guide. Scientific Software International.

Kalkan, F. (2016). Relationship between professional learning community, bureaucratic structure and organisational trust in primary education schools. Educational Sciences: Theory and Practice, 16(5), 1619-1637. DOI: 10.12738/estp.2016.5.0022

Kline, R. B. (2011). Principles and practice of structural equation modeling. The Guilford Press.

Liou, Y. H., \& Daly, A. J. (2014). Closer to learning: Social networks, trust, and professional communities. Journal of School Leadership, 24(4), 753-795. https://doi.org/10.1177/105268461402400407

Lomos, C., Hofman, R. H., \& Bosker, R. J. (2011). Professional communities and student achievement-a meta-analysis. School Effectiveness and School Improvement, 22(2), 121148. DOI: $10.1080 / 09243453.2010 .550467$

McVey, D. (2009). Parsonian influence and the effect of school climate and bureaucracy on the perceived effectiveness in schools (Unpublished Doctoral Dissertation). Derived from ProQuest Digital Dissertation. (UMI Number: 3365685).

Moolenaar, N. M., Daly, A. J., Cornelissen, F., Liou, Y. H., Caillier, S., Riordan, R., Wilson, K., \& Cohen, N. A. (2014). Linked to innovation: Shaping an innovative climate through network intentionality and educators' social network position. Journal of Educational Change, 15(2), 99-123. https://doi.org/10.1007/s10833-014-9230-4

Moolenaar, N. M., Sleegers, P. J., \& Daly, A. J. (2012). Teaming up: Linking collaboration networks, collective efficacy, and student achievement. Teaching and Teacher Education, 28(2), 251-262. https://doi.org/10.1016/j.tate.2011.10.001 
Ogdem, Z. (2015). Mesleki ogrenme toplulugu olarak ilkogretim okullarinda takim liderligi ve orgut iklimi (Doctoral Thesis). Retrieved from YOK TezMerkezi. (429388.)

Olivier, D.F., Hipp, K.K. \& Huffman, J.B. (2003). Assessing schools as PLCS. In: J.B. Huffman and KK. Hipp (Eds.), Reculturing schools as professional learning communities (pp. 67-74). Scarecrow Press.

Ozer, N. (2010). Ilkogretim okullarinin orgutsel diriklik, burokratiklik ve orgut normlari acisindan analizi (Master Thesis). Retrieved from YOK Tez Merkezi. (270192.)

Ozturk, N. (2001). Liselerde burokratiklesme ve ogretmenlerin stres duzeyleri (Doctoral Thesis). Retrieved from YOK Tez Merkezi. (103843.)

Sorensen, J. B. (2007). Bureaucracy and entrepreneurship: Workplace effects on entrepreneurial entry. Administrative Science Quarterly, 52(3), 387-412. https://doi.org/10.2189/asqu.52.3.387

Sumer, N. (2000). Yapisal esitlik modelleri: Temel kavramlar ve ornek uygulamalar [Structural equation models: Basic concepts and sample applications]. Turk Psikoloji Yazilari, 3(6), 49-74.

Tabachnick, B. G., \& Fidell, L. S. (2007). Structural equation modeling. Using multivariate statistics, 3, 676-780.

Tabak, H., \& Sahin, F. (2020). Investigating the relationship between school effectiveness, professional learning communities, school culture and teacher characteristics. Education Reform Journal, 5(2), 45-59.

Tarter, C. J. \& Hoy, W. K. (2004). A systems approach to quality in elementary schools: A theoretical and empirical analysis. Journal of Educational Administration 42(5), 539554. https://doi.org/10.1108/09578230410554052

Tuzel, E. (2010). Ilkogretim okullarinin burokratiklesme duzeyi ile ogretmenlerin orgutsel bagliliklari arasindaki iliski (Ankara ili ornegi) (Master Thesis). Retrieved from YOK Tez Merkezi. (278219)

Vescio, V., Ross, D., \& Adams, A. (2008). A review of research on the impact of professional learning communities on teaching practice and student learning. Teaching and Teacher Education, 24(1), 80-91. https://doi.org/10.1016/j.tate.2007.01.004

Wu, J. H., Hoy, W. K., \& Tarter, C. J. (2013). Enabling school structure, collective responsibility, and a culture of academic optimism. Journal of Educational Administration,51(2), 176193. https://doi.org/10.1108/09578231311304698

Zeytin, N. (2008). Illkogretim okullarinda burokratiklesme ve okul kulturu (Master Thesis). Retrieved from YOK Tez Merkezi. (220330)

\section{Biographical notes:}

Dr Fatih Sahin is a research assistant in the Department of Educational Administration at the Education Faculty of Gazi University. His research in the field focuses on educational administration and organisational behaviour.

iD https://orcid.org/0000-0002-6579-2550

Kubra Yenel is a research assistant in the Department of Educational Administration at the Education Faculty of Gazi University. Her research focuses on organisational behaviour, organisational culture, educational administration quality, and administrator training.

iD https://orcid.org/0000-0002-4237-9763 